\title{
Article \\ Separating Silver from Tin Silver Alloy Residue: Effect of Agitation Rate
}

\author{
Juliette Confiance Kabatesi ${ }^{1,2}\left(\mathbb{D}\right.$ and Jei-Pil Wang ${ }^{1, *(\mathbb{C})}$ \\ 1 Department of Metallurgical Engineering, Pukyong National University, Busan 48513, Korea; \\ kabatesijulietconfiance@gmail.com \\ 2 Department of Mining Engineering, University of Rwanda, Kigali, Rwanda \\ * Correspondence: jpwang@pknu.ac.kr; Tel.: +82-51-629-6341
}

check for

updates

Citation: Kabatesi, J.C.; Wang, J.-P. Separating Silver from Tin Silver Alloy Residue: Effect of Agitation Rate. Metals 2022, 12, 177. https:// doi.org/10.3390/met12020177

Academic Editor: Antoni Roca

Received: 1 December 2021

Accepted: 13 January 2022

Published: 19 January 2022

Publisher's Note: MDPI stays neutral with regard to jurisdictional claims in published maps and institutional affiliations.

Copyright: () 2022 by the authors. Licensee MDPI, Basel, Switzerland. This article is an open access article distributed under the terms and conditions of the Creative Commons Attribution (CC BY) license (https:// creativecommons.org/licenses/by/ $4.0 /)$.

\begin{abstract}
In this paper, research on the effects of agitation rate for desilvering tin silver alloy residue by using pyrometallurgy was carried out. SnAg alloy residue with $92 \mathrm{wt} . \%$ tin and $3.56 \mathrm{wt} . \%$ silver was used in this study, and $99.999 \mathrm{wt} . \%$ zinc was added as metal solvent. Residues were melted to a temperature of $400^{\circ} \mathrm{C}$ for enriching tin silver alloy. The obtained tin silver alloy was melted in a temperature range of $450^{\circ} \mathrm{C}$ to $500^{\circ} \mathrm{C}$ by adding zinc to evaluate zinc dissolution. The obtained tin silver zinc was agitated at different agitation rates for $20 \mathrm{~min}$ at a temperature of $480^{\circ} \mathrm{C}$, then cooled down while stirring to an eutectic point of tin zinc alloy $\left(198.9^{\circ} \mathrm{C}\right)$ to remove silver zinc dross. X-ray Fluorescent-1800 (XRF-1800) and Field Emission Scanning Electron Microscopy Energy Dispersive Spectroscopy (FE-SEM-EDS) analyses were performed in this research. Different factors including holding time, zinc dissolution, agitation time and agitation rate were evaluated. The results revealed that an agitation rate of $600 \mathrm{RPM}, 25 \% \mathrm{Zn}$ and $60 \mathrm{~min}$ at a temperature of $198.9^{\circ} \mathrm{C}$ were efficient. Zinc silver was removed as dross every $20 \mathrm{~min}$ to get $92 \%$ silver separation efficiency, and the use of supergravity centrifuge is highly recommended to get best separation efficiency.
\end{abstract}

Keywords: tin silver alloy residue; pyrometallurgy; silver extraction; thermodynamics; environmental issues; valuable metals; agitation rate

\section{Introduction}

Silver has wide applications in electronics, petroleum engineering, chemical and refining industries, jewelry production and alloying [1,2]. Nowadays, the major challenge is the increasing demand for precious metals and alloys while the natural metal resources are becoming exhausted [3]. According to report by Scottsdale, Bullion and Tale in 2018, the status of silver production is based on mine production and scrap. In their report, it is mentioned that there has been a deficit in silver supply since 2006, while demand is increasing due to industrial expansion. In 2018, The demand silver in jewelry increased about 39 million ounces, industrial silver demand increased at about 50 million ounces, solar cell silver demand increased about 80 million ounces, and minting coins and bars increased more than 100 million ounces [4]. A possible proposed solution is recycling. Tin lead alloys were known to be used as solder materials for packaging and interconnecting electronic components. However, due to the proved toxicity of lead and its environmental impacts, different countries have taken measures to reduce the use and release of lead into the environment with strict regulations including waste of electrical and electronic equipment (WEEE) and restriction of the use of certain hazardous substances (RoHS) $[5,6]$. This has resulted in the use of lead-free alloys such as tin silver copper alloy ( $\mathrm{SnAgCu}$ ), tin silver bismuth alloy (SnAgBi), tin silver zinc (SnAgZn) and tin silver alloy (SnAg) which can be applied in different areas including phosphate baths due to their physical, chemical and thermodynamic properties [7,8]. Considering all the suggested alloys, tin silver and tin silver copper alloys are excellent ones to use [5]. The increasing use of tin 
silver alloy increases its residue and metal waste such as tin, silver and other residues in the environment that are harmful to the human body (for example the regulatory limit for tin residue in drinking water is $0.10 \mathrm{mg} / \mathrm{L}$ while for silver it is $0.05 \mathrm{mg} / \mathrm{L}$ [9]), as well as ecosystems in general [10].

Silver is ranked as the second most toxic metal after lead due to its bioaccumulation in aquatic organisms and first as having the most adverse to environmental effects due to the hazardous materials or strong acids in its waste including cyanide, sulfuric acid, cadmium, lead and arsenic. [11]. This research was conducted to decrease silver demand on the market as well as protect the environment by recycling the silver contained in waste, since it was proved that by increasing silver waste, we increase hazardous materials in the environment. Despite the negative impacts of tin silver alloy waste, it can be used as the best alternative source of metals through recycling.

At present, different studies have been carried out examining the extraction and separation of silver from secondary sources such as printed circuit, electronic, etc. This involves the use of hydrometallurgy routes [12,13] such as hydrochloric acid [14] and nitric acids [15] which are not economical due to high consumption of reagents and nitrogen toxicity to humans [16]. Different research work carried out to extract and separate different metals from lead-free solders has focused on major metals in alloys such as tin by using different methodologies such as the application of microwaves for recovering tin from tin silver copper alloy [17-19]; however, there is a previous study on separating silver by using a pyrometallurgical method [20], but the process has different drawbacks such as high costs due to the long cyclic process.

In this research, a study on the effects of agitation rate using a programmable stirrer and zinc as metal solvent was carried out with the main goal of finding an efficient method to recover silver from tin silver alloy residues. It is hypothesized that finding an efficient agitation rate can contribute to the reduction of number of cycles required to separate silver. In this work, silver was selected as a metal solvent based on solubility and the stronger affinity of silver to zinc than liquid tin.

Therefore, zinc was preferably selected as a metal solvent and different agitation rates were used to evaluate its effect on the separation of silver from tin silver alloy residue.

\section{Materials and Methods}

\subsection{Materials}

In this study, tin silver alloy residue with $92 \mathrm{wt} \% \%$ tin and $3.56 \mathrm{wt} . \%$ silver with lead, copper, zinc and manganese as metal impurities and different refractory impurities was used. High purity zinc ingots of $99.999 \%$ were selected to be used as a metal solvent.

A self-designated ceramic propeller and programable stirrer were used to control agitation rate and an induction furnace (Figure 1) was used for melting and cooling the sample and ceramic scoop was used in tilting and skimming process.

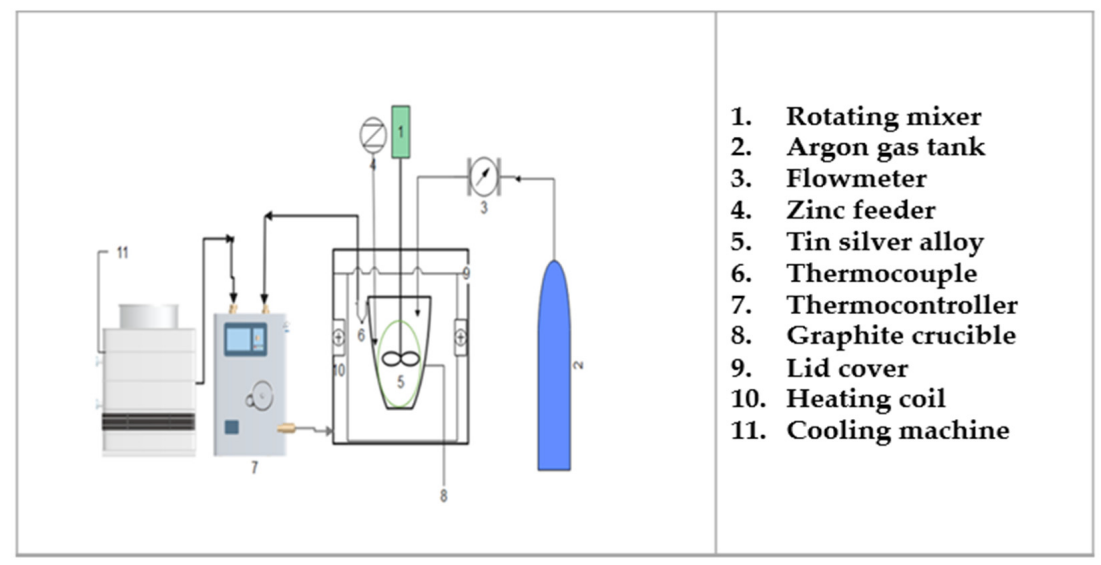

Figure 1. Schematic diagram of the induction furnace used in this work. 
In this study, the residue contents were analyzed with a Shimadzu X-ray fluorescent analyzer-1800 (XRF-1800, Kyoto, Japan) (Table 1), while quantitative and qualitative (mapping and point analysis) were analyzed using a scanning electron microscope (cold type) (FE-SEM) manufactured by JEOL (JEM-2100F) for energy dispersive spectrometry (EDS).

Table 1. Tin silver alloy residue XRF metal analysis results.

\begin{tabular}{|c|c|c|c|c|c|c|c|}
\hline Compositions of Elements & Ag & Sn & $\mathrm{Cu}$ & Mn & $\mathbf{P b}$ & $\mathrm{Zn}$ & $\mathrm{SiO}_{2}$ \\
\hline wt.\% & 3.56 & 92.0 & 0.780 & 0.300 & 1.36 & 1.12 & 0.880 \\
\hline
\end{tabular}

\subsection{Experimental Procedures}

The induction furnace made from INSUNG from Korea used in this study consisted of a controller and heat box connected to a cooling machine. The controller regulates the heating temperature by adjusting the voltage. A graphite crucible was used for better conduction; the temperature was measured using a K-type thermocouple and the programable stirrer made from Wonju, South Korea by Daihan scientific co.ltd was connected to mix zinc into tin silver alloy, a programmable stirrer was in the middle of the metal bath for better mixing (Figure 2).

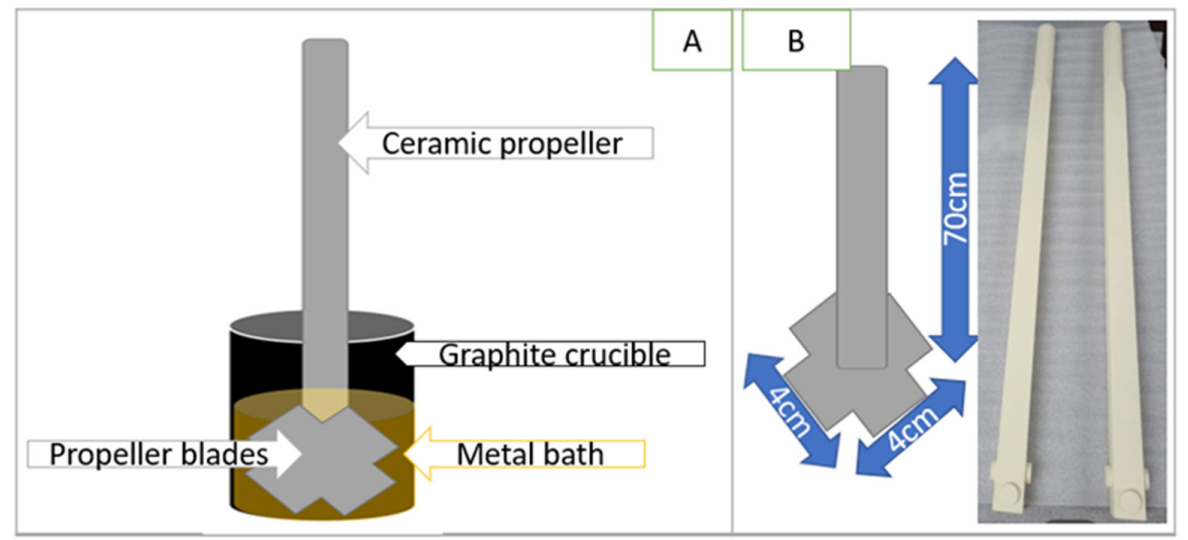

Figure 2. Position of propeller in metal bath (A) and propeller dimensions (B).

The temperature rate of the induction furnace was $10^{\circ} \mathrm{C}$ per minute. Argon gas was charged to a heater box to create an atmosphere and avoid oxidation, and the experiment was conducted at a maximum temperature of $480^{\circ} \mathrm{C}$.

Samples were prepared by measuring and quantifying their composition, and the tin silver alloy residue and zinc were cut into $3 \mathrm{~cm}$ and $0.1 \mathrm{~mm}$ pieces, respectively, and $127 \mathrm{~g}$ of tin silver alloy residue were melted using the induction furnace. All the equipment used in this study were provided by Pukyong National University.

Two-step experiments were conducted to investigate the effects of agitation and separation efficiency. First, the tin silver alloy residue was enriched to remove impurities and tin silver alloy enrichment was used to get tin silver alloy by gravity difference. Then it was carried out to further the process of separating silver from tin silver alloy melts by evaluating the effects of agitation rates. The detailed procedures are shown below.

\subsubsection{Tin Silver Alloy Enrichment Process}

First, $127 \mathrm{~g}$ of tin silver residue was placed into a set of self-designated graphite crucibles with a height of $15 \mathrm{~cm}$ and inner diameter of $5 \mathrm{~cm}$. A $0.9 \mathrm{~mm}$ hole was drilled into the bottom of graphite crucible, and $0.3 \mathrm{~mm}$ of graphite felt shipped online was placed at the bottom of the upper crucible to filtrate molten tin silver alloy residue and small solid particles. A similar graphite felt was placed on the top of the tin silver residue to avoid oxidation during the separation process. The tin silver alloy residue was heated to $400{ }^{\circ} \mathrm{C}$ 
to remove different impurities including tin, zinc, silicon dioxide, lead, chromium, carbon, and manganese. These impurities could be removed by gravity. This enrichment process resulted in pure tin silver alloy. The impurities and filtered tin silver alloy were obtained from the upper and lower crucible, respectively, and were prepared for the experiment.

\subsubsection{Separation of Tin Silver Alloy}

To separate silver from the filtered silver tin alloy obtained from the previous experiment, a second experiment was carried out in an induction furnace with zinc as a metal solvent and different agitation rates were used to evaluate the most effective one. The filtered $112 \mathrm{~g}$ of tin silver alloy was placed into a graphite crucible with a height of $15 \mathrm{~cm}$ and inner diameter of $5 \mathrm{~cm}$ and then melted at a temperature of $480{ }^{\circ} \mathrm{C}$ where the silver zinc intermetallic compounds could be formed. Next, $25 \%$ zinc was added with 20 min of agitation and different agitation rates such as 200 RPM, 400 RPM, and 600 RPM were evaluated to study their efficiency in separating silver from the tin silver alloy. Then it was cooled while stirring down to the eutectic temperature of tin zinc $\left(198.9^{\circ} \mathrm{C}\right)$. A holding and agitation time of $60 \mathrm{~min}$ was maintained while removing silver zinc dross every $20 \mathrm{~min}$.

\subsection{Methods}

The methodology used in this study was based on the thermodynamic properties of tin silver alloy as well as zinc as a metal solvent. Tin silver alloy phase as in the Figure 3, tin zinc phase (Figure 4) and silver zinc phase (Figure 5) were taken into consideration before using zinc as a solvent.

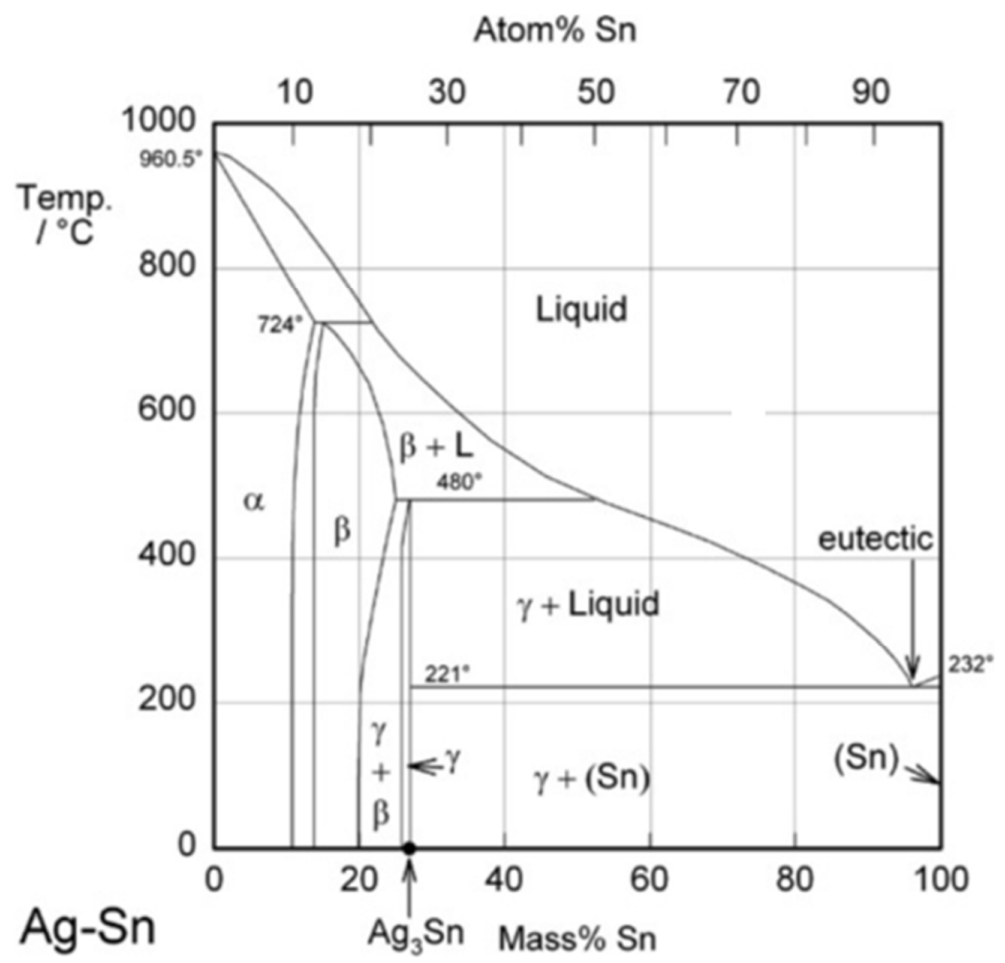

Figure 3. Tin silver alloy phase diagram [20]. 


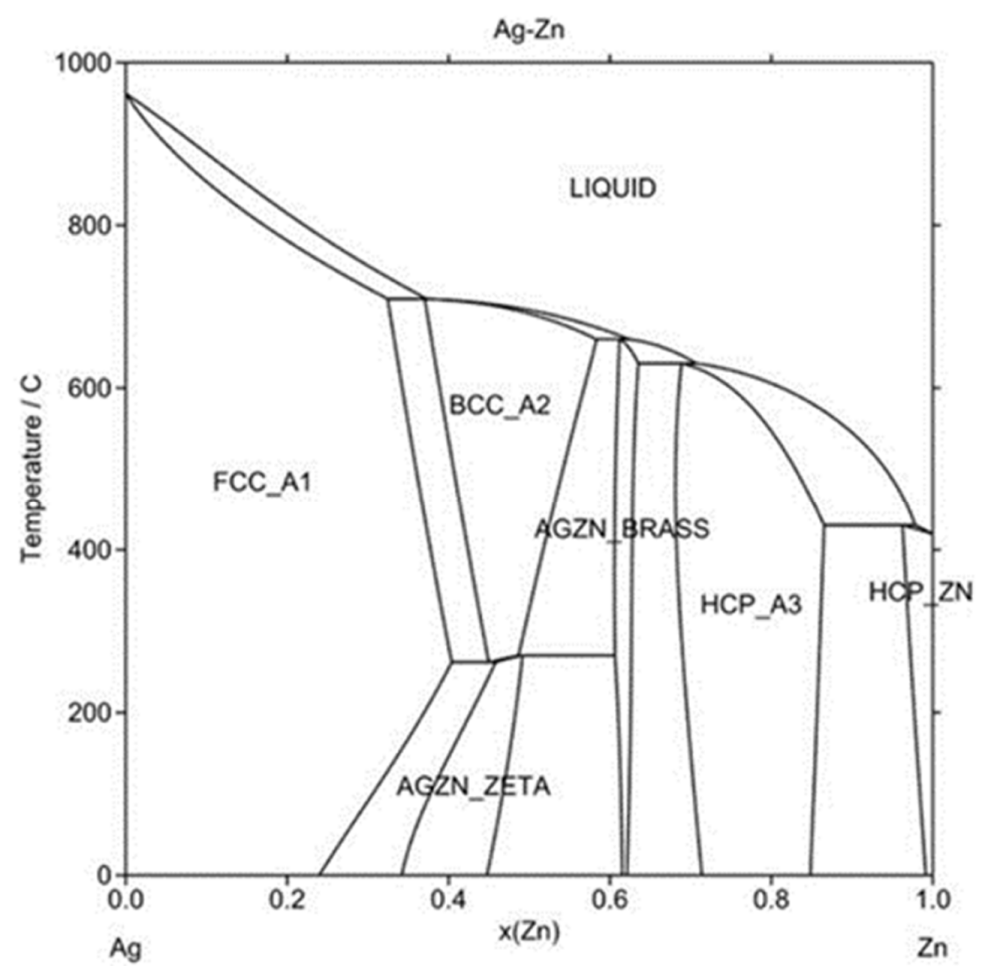

Figure 4. Silver zinc phase diagram. Reprinted with permission from ref. [2]. Copyright 2021 Springer Nature.

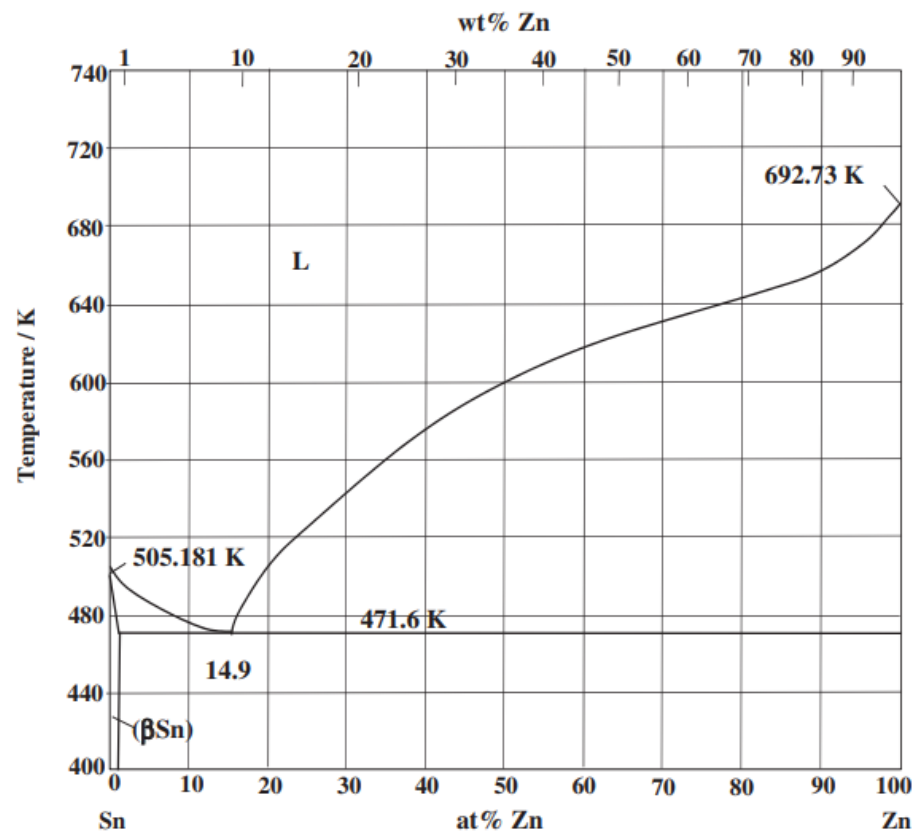

Figure 5. Tin zinc phase diagram. Reprinted with permission from ref. [21]. Copyright 2021 Elsevier.

According to the above binary phase diagrams, zinc was added at a temperature range of $450{ }^{\circ} \mathrm{C}$ to $500{ }^{\circ} \mathrm{C}$, where different silver zinc intermetallic compounds such as AgZn3, Ag5Zn8 and AgZn can be formed, and the dissolution of zinc in tin silver alloy in that temperature range was evaluated. The eutectic point of tin zinc alloy was 198.9 ${ }^{\circ} \mathrm{C}$ (Figure 4). This implies that if zinc is added and agitated between $450{ }^{\circ} \mathrm{C}$ to $500{ }^{\circ} \mathrm{C}$, different silver zinc intermetallic compounds will be formed to be removed as dross at a temperature of $198.9^{\circ} \mathrm{C}$ where tin zinc alloy is formed. This study was limited to the 
separation silver to obtain silver zinc, and an experimental chart of the whole experiment is shown below (Figure 6).

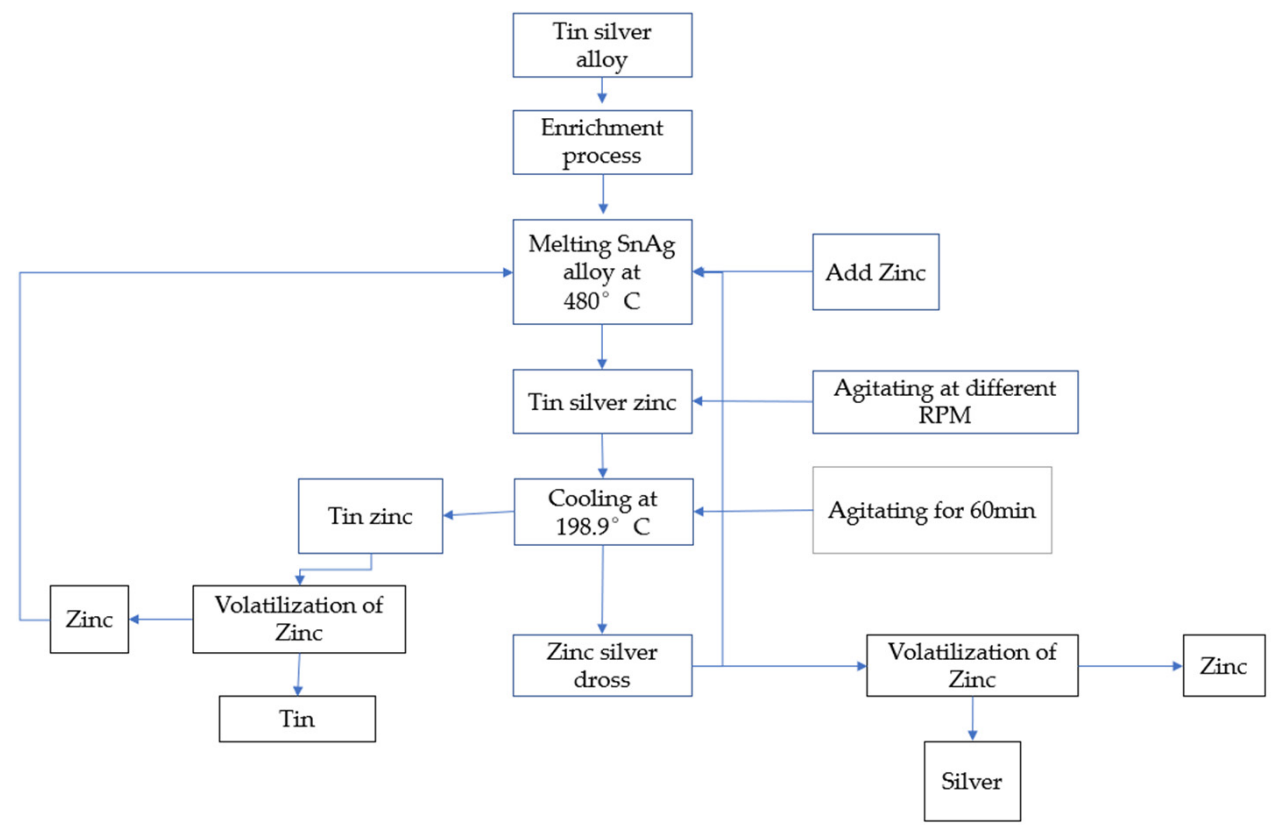

Figure 6. Experimental flowchart of model.

\section{Results and Discussion}

\subsection{Tin Silver Enrichment Results}

The separation of tin silver alloy and impurities was examined by using FE-SEM-EDS analysis where the impurities removed were analyzed for silver contents. The results revealed that no silver was lost in impurities (Figure 7).

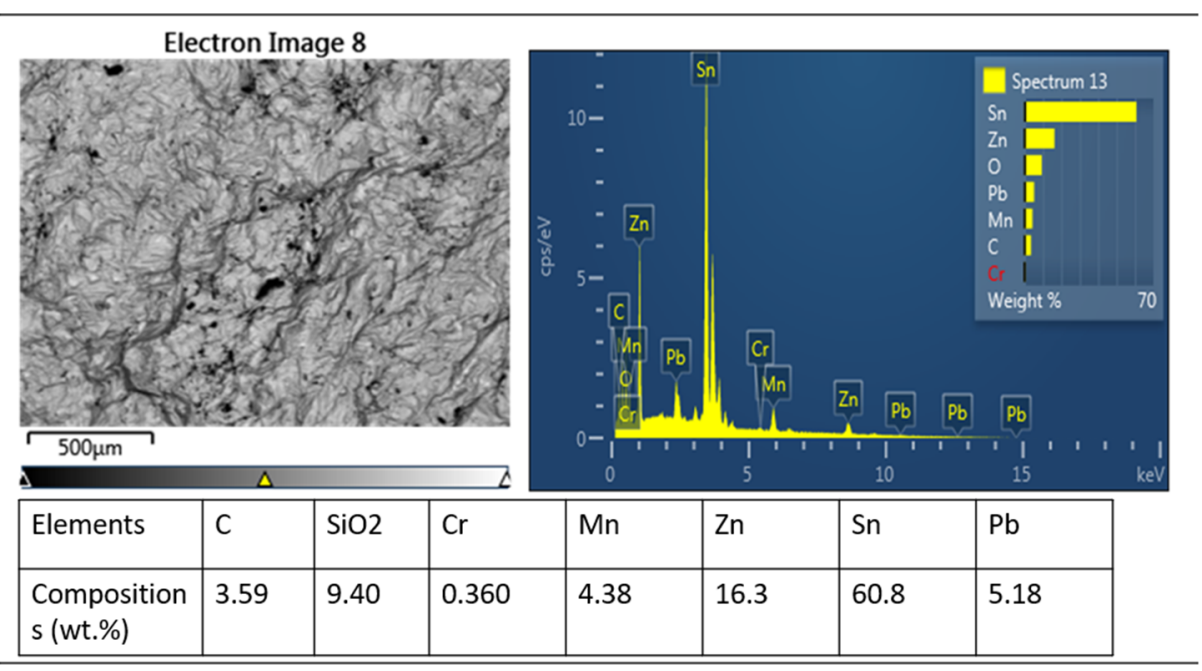

Figure 7. Removed impurities FE-SEM (EDS) analysis with a holding time of $30 \mathrm{~min}$.

The refractory oxides were removed by melting tin silver alloy residue at $400{ }^{\circ} \mathrm{C}$ under normal gravity and filtered by using graphite felt within a period of $30 \mathrm{~min}$ for complete separation (Figure 8). 


\section{silver lost (\%)}

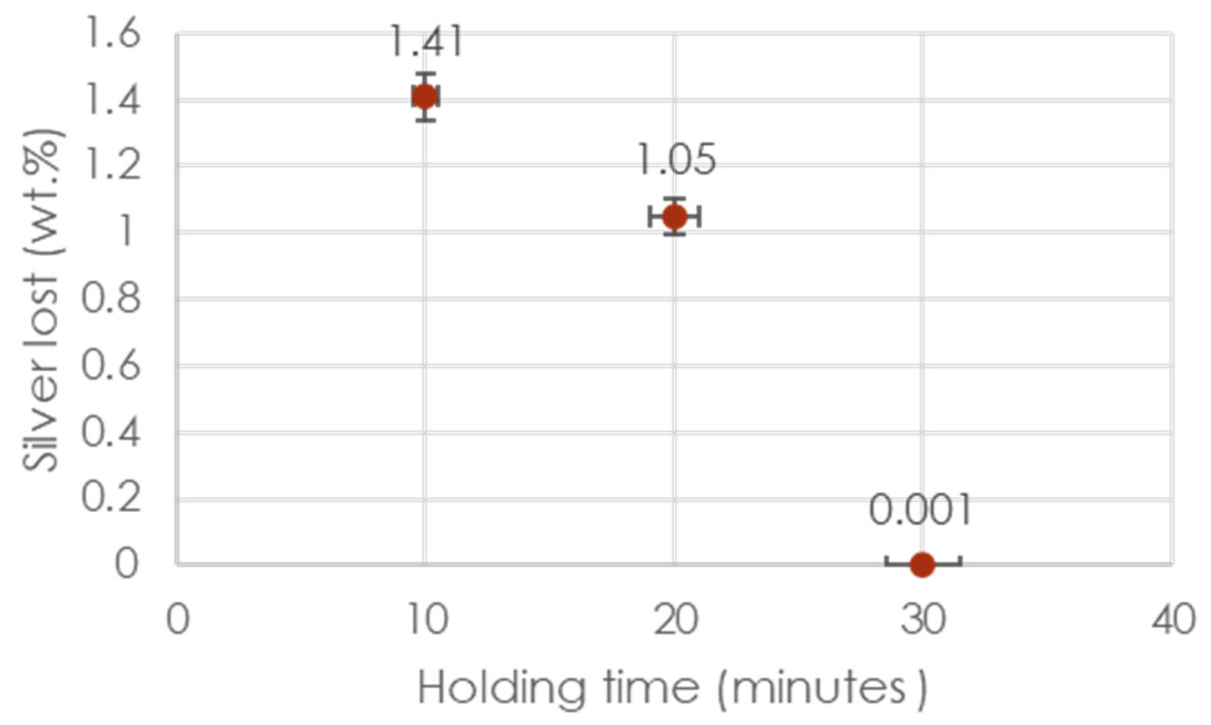

Figure 8. Silver weight percent lost in impurities during enrichment process.

The enriched tin silver alloy was analyzed using FE-SEM-EDS to identify and quantify the impurities remaining in the tin silver alloy (Figure 9). To obtain tin silver alloy after the removal of impurities the samples were cooled to the eutectic temperature of tin silver alloy $\left(221^{\circ} \mathrm{C}\right)$. The enriched tin silver alloy containing $94.15 \mathrm{wt} . \%$ tin and $4.06 \mathrm{wt} . \%$ silver was used for further processing to separate silver.

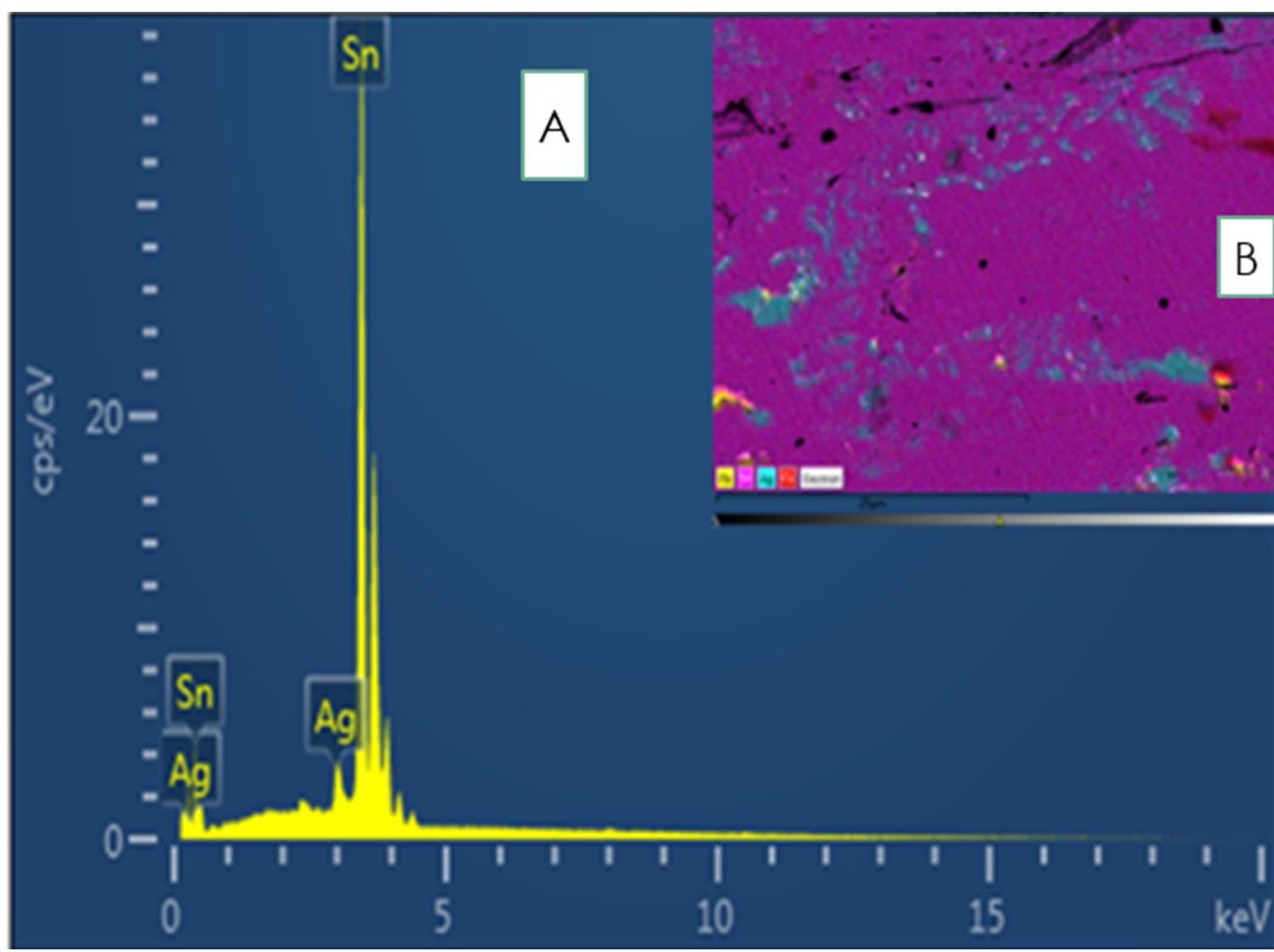

Figure 9. Enriched tin silver alloy FE-SEM (EDS) (A); mapping and point analysis (B). 
3.2. Separation of Silver from Tin Silver Alloy

3.2.1. Amount of Zinc Added

The amount of zinc added for the tin silver alloy desilvering process was evaluated by measuring the dissolution of zinc at $480{ }^{\circ} \mathrm{C}$, and the results showed that the maximum efficient amount of zinc to be added was $25 \%$ of the amount of tin silver alloy used for the first separation stage (Figure 10).

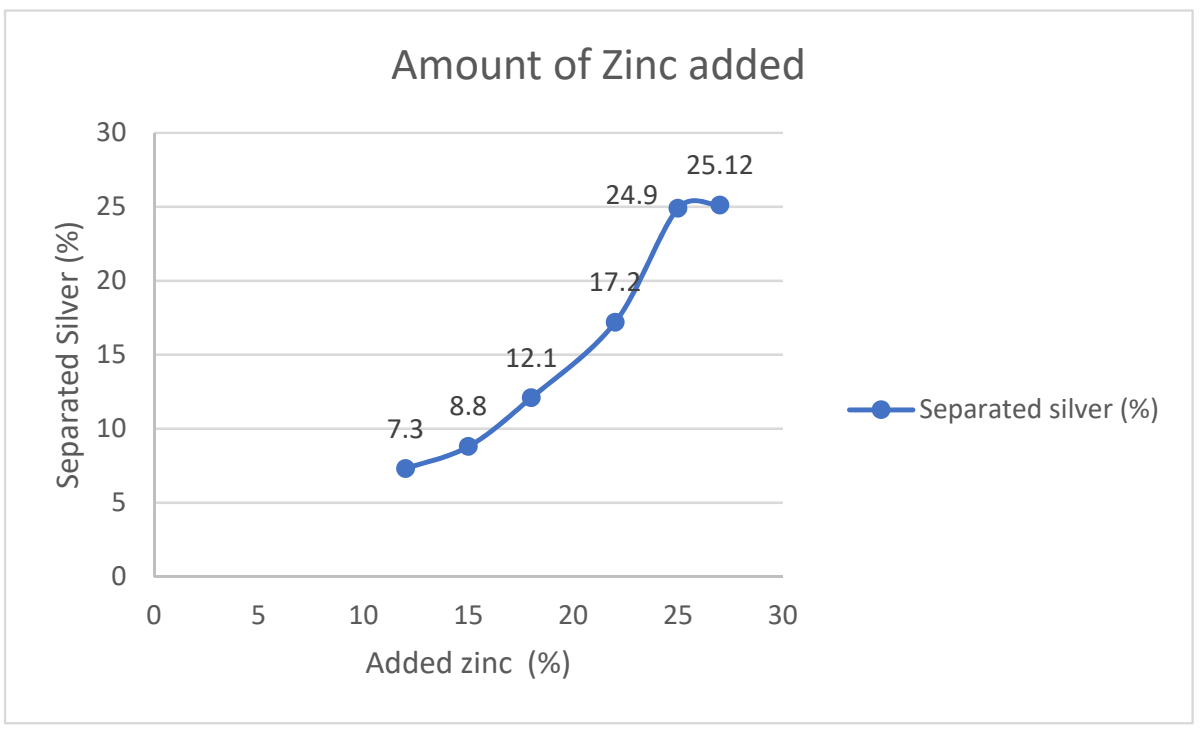

Figure 10. Amount of separated silver depending on amount of zinc added at $480{ }^{\circ} \mathrm{C}$ : first silver separation, cooling temperature of $198.9^{\circ} \mathrm{C}$, agitation rate of $400 \mathrm{RPM}$.

\subsubsection{Effect of Holding Time}

The graph below shows the zinc dissolution and effects of holding time without agitation. This was experimented to evaluate the behavior of zinc dissolution depending upon the holding time (Figure 11).

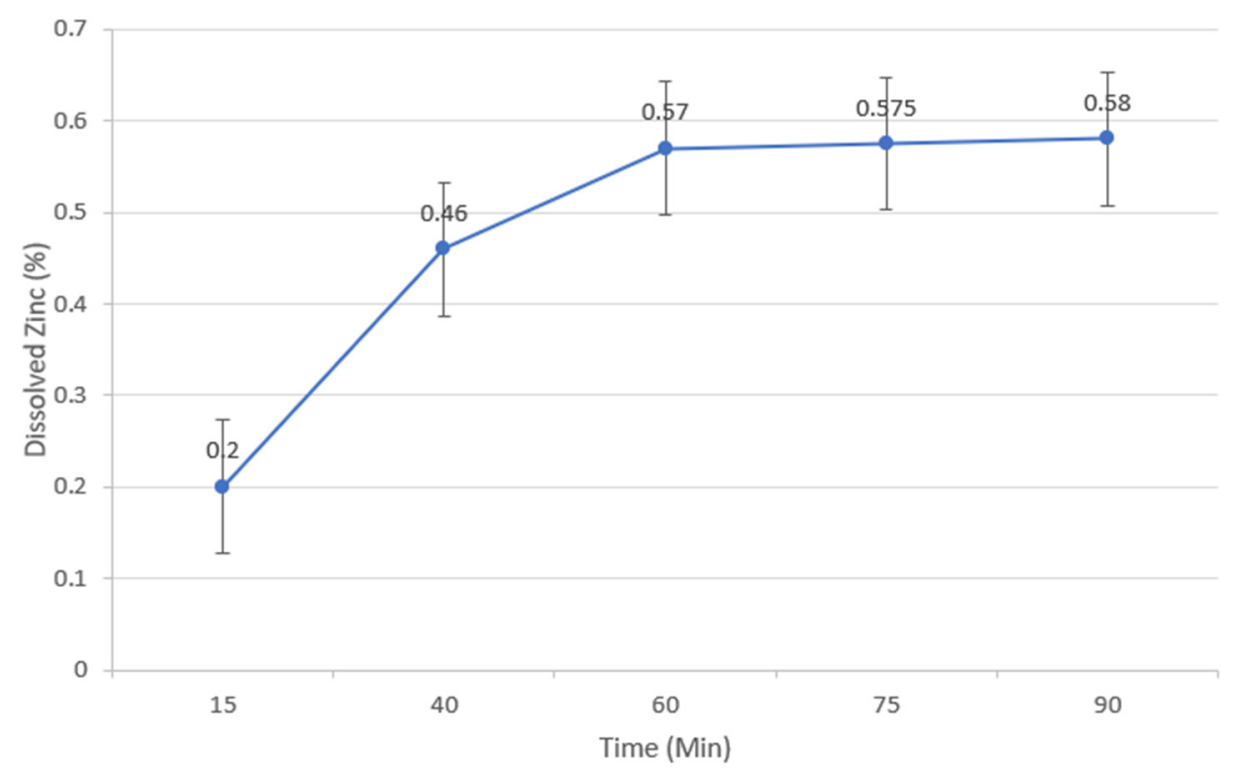

Figure 11. Holding time evaluation of $25 \%$ zinc dissolution in tin silver alloy before agitation. 


\subsubsection{Effects of Agitation}

After enriching the tin silver alloy, zinc was added and the effects of holding time and agitation were evaluated. The results of the effect of holding time without agitation rate are shown below (Figure 12).
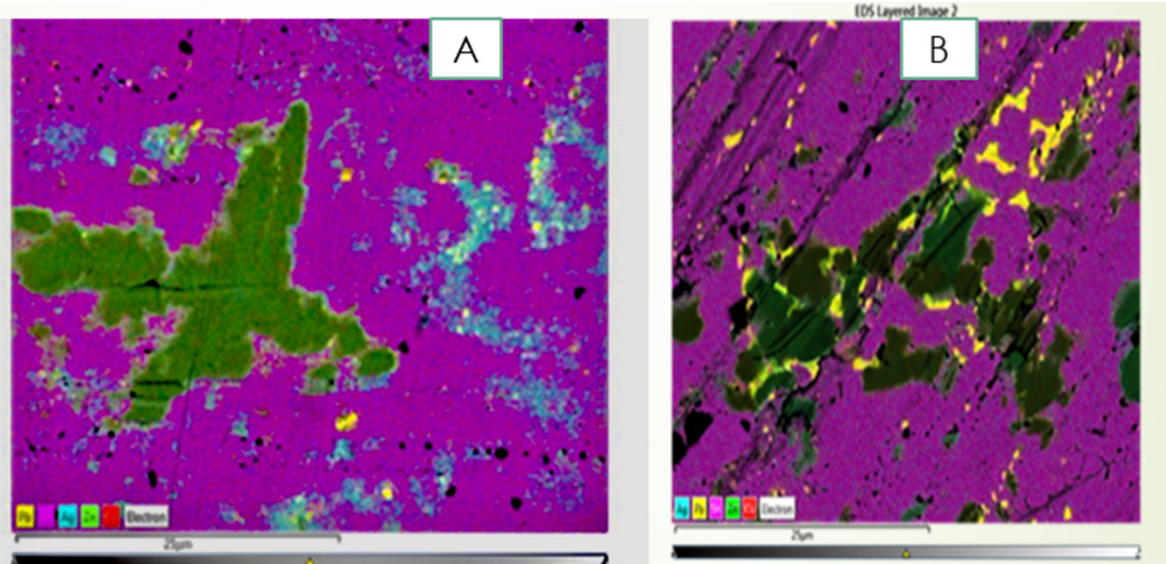

Figure 12. FE-SEM image of effects of zinc addition to tin silver alloy without agitating (A) and after agitating at 400 RPM (B).

Silver can't be separated through cementation due to liquid tin metaphase and zinc silver alloy phase density difference (Figure 12), so agitation was done to float silver zinc as dross (Figure 13).

\section{silver zinc formed (\%)}

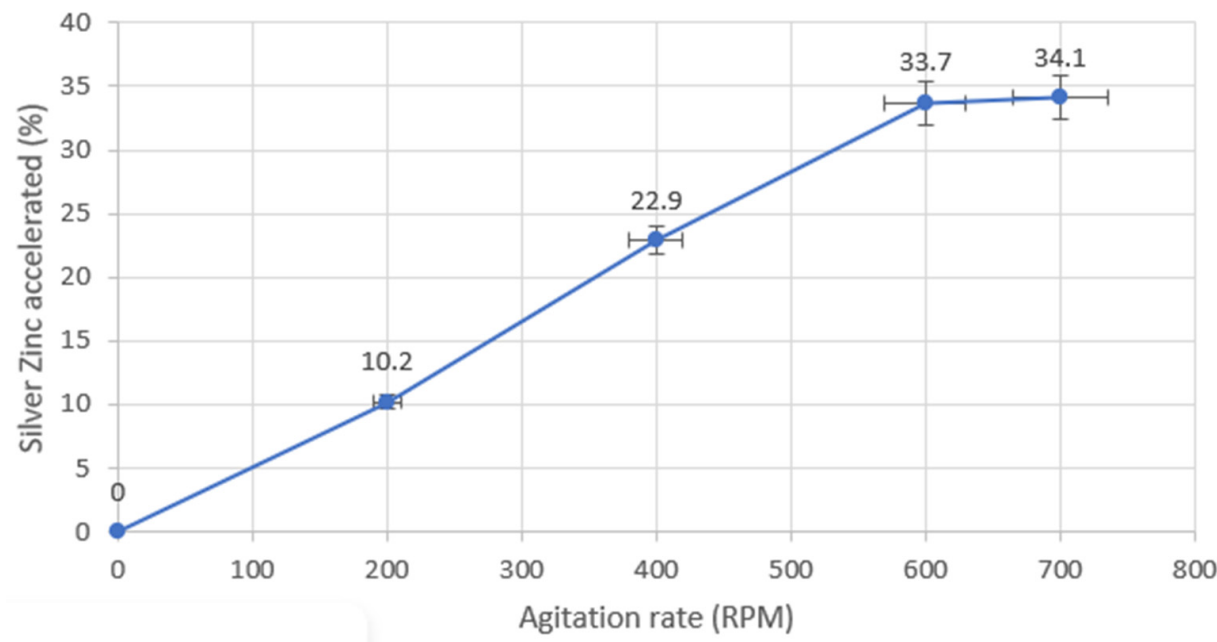

Figure 13. Effects of agitation rate on desilvering process in first separation conditions: cooling temperature of $198.9^{\circ} \mathrm{C}$ with 20 min agitation time.

\subsubsection{Effects of Agitation Time}

In this study, the agitation time was considered, and Figure 14 shows he effects of agitation time before removing zinc silver dross from liquid tin. 


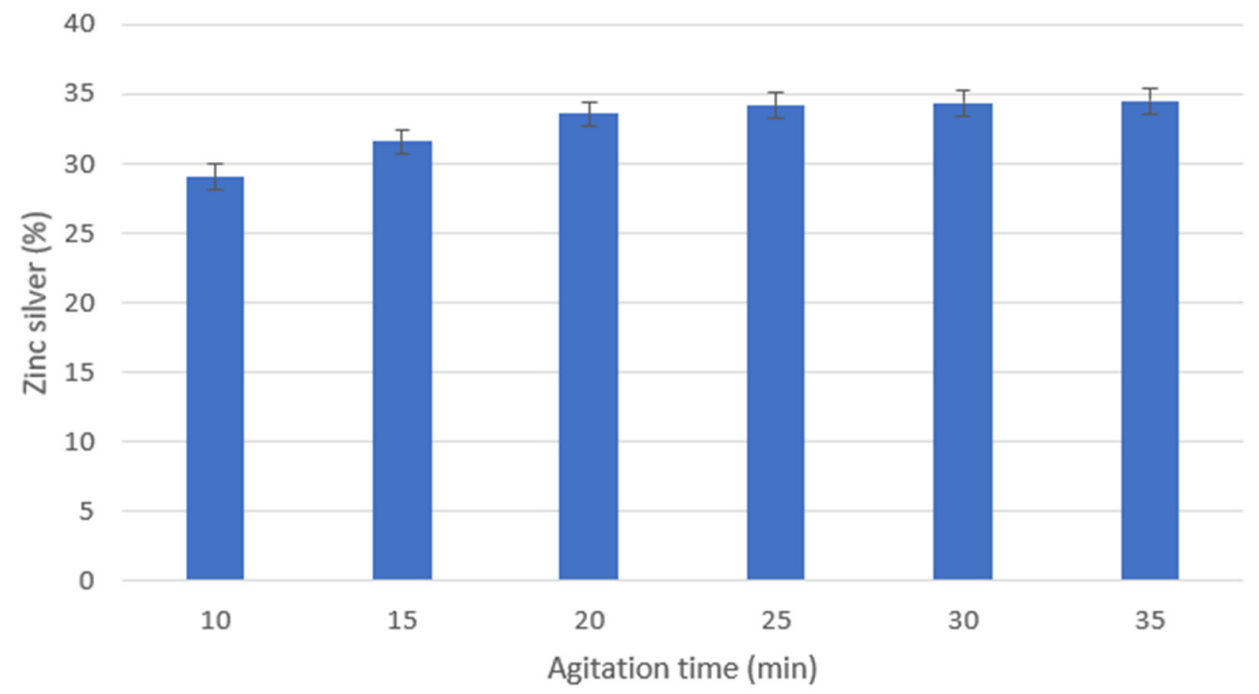

Figure 14. Effects of agitation time before skimming zinc silver from liquid tin metaphase at an agitation rate of 600 RPM.

\subsubsection{Agitation Time, Agitation Rate and Desilvered Silver}

Silver separation efficiencies were evaluated at different agitation times and rates (Figure 15). This was done by measuring the separation efficiency of zinc silver at different agitation times with respect to the RPM used. To obtain the separation efficiency, the formula below was used:

$$
S E=\frac{S i-S f}{S i} \times 100
$$

where $S E$ stands for separation efficiency, $S i$ stands for the weight of silver in the tin silver alloy residue before separation and $S f$ stands for the weight of silver obtained after separation.

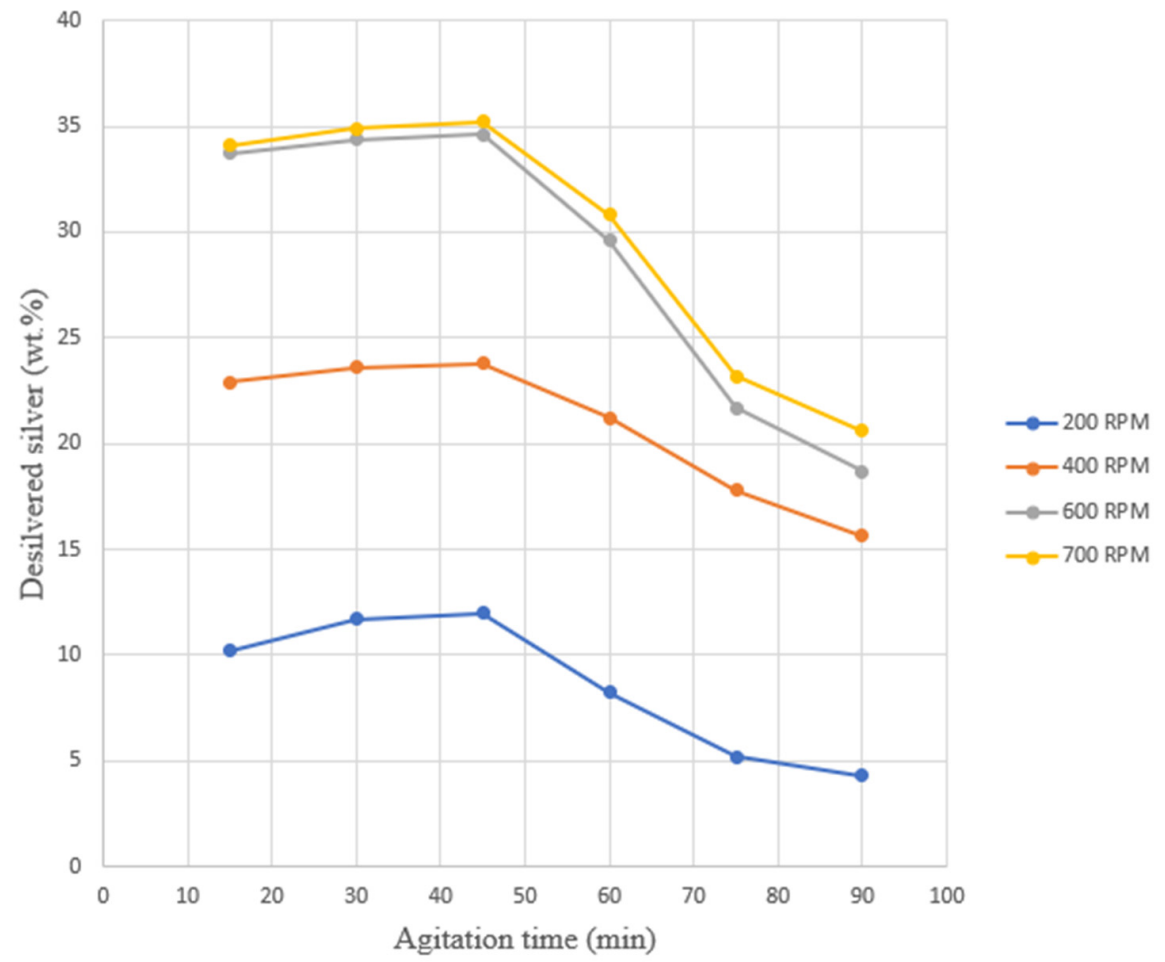

Figure 15. Evaluating separation efficiency with respect to agitation time at different agitation rates with $25 \%$ zinc and $20 \mathrm{~min}$ of agitation at a temperature of $480^{\circ} \mathrm{C}$. 
Figure 15 shows the summarized results obtained in this analysis:

\subsection{Discussion}

The whole process involved separating silver from tin silver alloy. This was done by adding zinc to tin silver alloy, and zinc was selected based on the tin silver and tin zinc phase diagram. In the cooling process, tin zinc and zinc silver dross were formed. Zinc silver dross was removed using a skimming process. Melting of tin silver alloy at a temperature of $400{ }^{\circ} \mathrm{C}$, which is above the eutectic point of tin silver alloy to lead to the removal of different impurities including tin, as shown in Figure 7. Due to the increase in tin liquid metaphase (tin normally melts at $231^{\circ} \mathrm{C}$ ), there no silver was lost at a holding time under $30 \mathrm{~min}$. As we increased the holding time past $30 \mathrm{~min}$, melted tin and impurities increased (Figure 8) and were removed to leave enriched tin silver alloy Figure 9.

Figure 10 shows that the percentage of separated silver is a function of the amount of zinc added. In the first stage of separation with an agitation rate of 600 RPM and cooling temperature of $198.9^{\circ} \mathrm{C}$, separated silver increased with the increasing zinc amount, but at $25 \%$ the flow became steady, which shows the maximum zinc solubility in tin silver alloy.

Considering Figure 11, the effects of dissolving zinc into tin silver alloy without agitation was evaluated, and the results show that there is no-remarkable dissolution since only $0.58 \%$ can be achieved for a time of $1 \mathrm{~h} 30 \mathrm{~min}$. This implies that the cementation process of silver from tin silver alloy by using zinc is not efficient (Figure 12A) Hence, zinc can be dissolved in tin silver alloy by accelerating its motion by agitating at different revolutions per minute. Figure 12B shows that at 400 RPM different silver zinc intermetallic compounds were formed, and this proved the effects of agitation.

Figure 13 shows the effects of agitation rate on the dissolving and accelerating desilvering process in the first stage of separation with a cooling temperature of $198.9^{\circ} \mathrm{C}$. The results revealed that by increasing the agitation rate, zinc is dissolved in tin silver alloy, and it also accelerates zinc silver to float as dross, which was skimmed off and measured to evaluate the efficiency of separating silver from tin silver alloy.

It was revealed that above $600 \mathrm{RPM}$, the recovered zinc silver became steady, and this was proved by comparing the desilvered zinc silver from 400 RPM, 600 RPM and 700 RPM, where the skimmed zinc silver was $22.9 \%, 33.7 \%$ and $34.1 \%$, respectively.

According to Figure 14, where the effects of agitation time before skimming zinc silver were evaluated, the results revealed that beyond $20 \mathrm{~min}$ of agitation there is no great difference in the quantity of silver separated from tin silver alloy due to the maximum solubility of zinc in zinc silver dross.

Based on experimental work done, the findings are as follows: An efficient agitation rate was found to be 600 RPM with an agitation time of 20 min before skimming. The efficient amount of zinc found to be $25 \%$ of tin silver alloy, and at least three stages (cycles) were needed to obtain at least $92 \%$ silver separation efficiency. Therefore, increasing the agitation rate to 600 RPM will increase silver separation efficiency and reduce the number of cycles to half. Since it still requires several cycles for efficient separation, the use of supergravity centrifugation is highly recommended as an efficient methodology to separate silver from tin silver alloy.

\section{Conclusions}

To conclude, it is possible to separate silver from tin silver alloy by using zinc as a metal solvent. By increasing the agitation rate, zinc silver separation can be accelerated, and the number of cycles reduced. In this study, the separation of silver from tin silver alloy residue took two steps. The enrichment of tin silver alloy and separating silver by increasing the agitation rate. The percentage of separated silver increased from $10.01 \%$ at $200 \mathrm{RPM}$ to $33.7 \%$ by using $600 \mathrm{RPM}$ as the agitation rate in the first step of separation where $25 \%$ zinc was added. The silver separation efficiency became $92 \%$ in the third stage of separation. The increase in the agitation rate increases separation efficiency and decreases time spent by reducing the number of separation stages. The whole experiment was safe, 
making it environmentally friendly and economical by reducing power consumption. As shown in Figure 6, future work will involve recovering silver, tin and zinc from silver zinc dross and tin zinc alloy, respectively.

Author Contributions: Conceptualization, J.C.K. and J.-P.W.; methodology, J.C.K.; software, J.C.K.; validation, J.C.K.; formal analysis, J.C.K.; investigation, J.-P.W.; resources, J.-P.W.; data curation, J.C.K.; writing — original draft preparation, J.C.K.; writing-review and editing, J.C.K. and J.-P.W.; visualization, J.-P.W.; supervision, J.-P.W.; project administration, J.-P.W.; funding acquisition, J.-P.W. All authors have read and agreed to the published version of the manuscript.

Funding: No funding was obtained during this work.

Data Availability Statement: The study didn't report any data.

Acknowledgments: This research was supported by the Basic Science Research Program through the National Research Foundation of Korea (NRF) funded by the Ministry Education (2019R1F104940513) and supported by the BB21+ Project in 2021.

Conflicts of Interest: The authors declare no conflict of interest.

\section{References}

1. Mutafoglu, T.H.; Tokat, E.; Tokat, H.A. Forecasting precious metal price movements using trader positions. Resour. Policy 2012, 37, 273-280. [CrossRef]

2. Mandal, M.; Moon, A.; Sangal, S.; Mondal, K. Nanoporous Ag template from partially sintered Ag-Zn compact by dezincification. Bull. Mater. Sci. 2014, 37, 1353-1367. [CrossRef]

3. Sensoy, A. Dynamic relationship between precious metals. Resour. Policy 2013, 38, 504-511. [CrossRef]

4. Coin, S.B. Silver Price Forecast. 2020. Available online: https://www.sbcgold.com/blog/silver-price-forecast-2020/ (accessed on 15 October 2021).

5. Hurtony, T.; Szakál, A.; Almásy, L.; Len, A.; Kugler, S.; Bonyár, A.; Gordon, P. Characterization of the microstructure of tin-silver lead free solder. J. Alloy. Compd. 2016, 672, 13-19. [CrossRef]

6. Moreira, F.R.; Moreira, J.C. Effects of lead exposure on the human body and health implications. Rev. Panam. Salud. Publica 2004 15, 119-129. [CrossRef] [PubMed]

7. Kubota, N.; Sato, E. The properties of silver-tin alloy deposits from pyrophosphate bath. Electrochim. Acta 1985, 30, 305-309. [CrossRef]

8. Ma, H.; Suhling, J.C. A review of mechanical properties of lead-free solders for electronic packaging. J. Mater. Sci. 2009, 44, 1141-1158. [CrossRef]

9. Turbini, L.J.; Munie, G.C.; Bernier, D.; Gamalski, J.; Bergman, D.W. Examining the environmental impact of lead-free soldering alternatives. In IEEE Transactions on Electronics Packaging Manufacturing; IEEE: Piscataway, NJ, USA, 2001; Volume 24, pp. 4-9.

10. Ma, Y.; Prasad, M.N.; Rajkumar, M.; Freitas, H. Plant growth promoting rhizobacteria and endophytes accelerate phytoremediation of metalliferous soils. Biotechnol. Adv. 2011, 29, 248-258. [CrossRef] [PubMed]

11. Ku, A.; Shapiro, A.; Kua, A.; Ogunseitan, O.; Saphores, J.; Schoenung, J. Lead-free solders: Issues of toxicity, availability and impacts of extraction. In Proceedings of the ECTC 53rd Annual Symposium, New Orleans, LA, USA, 27-30 May 2003.

12. Mishra, G.; Jha, R.; Rao, M.D.; Meshram, A.; Singh, K.K. Recovery of silver from waste printed circuit boards (WPCBs) through hydrometallurgical route: A review. Environ. Chall. 2021, 4, 100073. [CrossRef]

13. Bilesan, M.R.; Makarova, I.; Wickman, B.; Repo, E. Efficient separation of precious metals from computer waste printed circuit boards by hydrocyclone and dilution-gravity methods. J. Clean. Prod. 2021, 286, 125505. [CrossRef]

14. Kim, S.; Lee, J.-c.; Lee, K.-s.; Yoo, K.; Alorro, R.D. Separation of tin, silver and copper from waste Pb-free solder using hydrochloric acid leaching with hydrogen peroxide. Mater. Trans. 2014, 55, 1885-1889. [CrossRef]

15. Yoo, K.; Lee, J.-c.; Lee, K.-s.; Kim, B.-s.; Kim, M.-s.; Kim, S.-k.; Pandey, B.D. Recovery of Sn, Ag and Cu from Waste Pb-Free Solder Using Nitric Acid Leaching. Mater. Trans. 2012, 53, 2175-2180. [CrossRef]

16. Lee, S.-h.; Yoo, K.; Jha, M.K.; Lee, J.-c. Separation of Sn from waste Pb-free Sn-Ag-Cu solder in hydrochloric acid solution with ferric chloride. Hydrometallurgy 2015, 157, 184-187. [CrossRef]

17. Xu, L.; Peng, J.; Bai, H.; Srinivasakannan, C.; Zhang, L.; Wu, Q.; Han, Z.; Guo, S.; Ju, S.; Yang, L. Application of microwave melting for the recovery of tin powder. Engineering 2017, 3, 423-427. [CrossRef]

18. Henao, H.M.; Masuda, C.; Nogita, K. Metallic tin recovery from wave solder dross. Int. J. Miner. Processing 2015, 137, 98-105. [CrossRef]

19. Su, Z.; Zhang, Y.; Liu, B.; Lu, M.; Li, G.; Jiang, T. Extraction and separation of tin from tin-bearing secondary resources: A review. Jom 2017, 69, 2364-2372. [CrossRef]

20. Kim, B.-S.; Lee, J.-c.; Kim, S.-K. A Novel Cyclic Process Involving Zinc for Separating Silver from Lead-Free Solder Residue. Mater. Trans. 2010, 51, 1350-1353. [CrossRef]

21. Budman, E.; Stevens, D. Tin-zinc plating. Anti-Corros. Methods Mater. 1998, 45, 327-332. [CrossRef] 